This is the accepted version of the following article:

Renáta Šelešovská, Marie Herynková, Jana Skopalová, Pavlína Kelíšková-Martinková, Lenka Janíková, Petr Cankař, Petr Bednář and Jaromíra Chýlková. Oxidation Behavior of Insecticide Azoxystrobin and its Voltammetric Determination Using Boron-doped Diamond Electrode.

Electroanalysis. 10 January 2019. DOI https://doi.org/10.1002/elan.201800647

This article may be used for non-commercial purposes in accordance With Wiley-VCH Terms and Conditions for self-archiving".

This preprint version is available from https://hdl.handle.net/10195/74753 


\section{Electroanalysis}

\section{Oxidation behavior of insecticide azoxystrobin and its voltammetric determination using boron-doped diamond electrode \\ --Manuscript Draft--}

\begin{tabular}{|c|c|}
\hline Manuscript Number: & \\
\hline Article Type: & Full Paper \\
\hline Corresponding Author: & $\begin{array}{l}\text { Renáta Šelešovská, Assoc. Prof. } \\
\text { Univerzita Pardubice } \\
\text { Pardubice, Pardubice CZECH REPUBLIC }\end{array}$ \\
\hline Corresponding Author E-Mail: & renata.selesovska@upce.cz \\
\hline \multirow[t]{7}{*}{ Other Authors: } & Marie Herynková, Ing. \\
\hline & Jana Skopalová, Ph.D. \\
\hline & Pavlína Kelí̌ková-Martinková, Ing. \\
\hline & Lenka Janíková, Ph.D. \\
\hline & Petr Cankař, Assoc. Prof. \\
\hline & Petr Bednář, Assoc. Prof. \\
\hline & Jaromíra Chýlková, Prof. \\
\hline Requested Editor: & José M. Pingarrón, Editor_Europe \\
\hline Keywords: & $\begin{array}{l}\text { Pesticides; Azoxystrobine; Oxidation mechanism; Voltammetric determination; } \\
\text { Boron-doped diamond electrode }\end{array}$ \\
\hline Manuscript Classifications: & Electroanalytical chemistry \\
\hline \multirow[t]{3}{*}{ Suggested Reviewers: } & $\begin{array}{l}\text { Miroslav Gal, Assoc. Prof. } \\
\text { Slovac University of Technology, Bratislava, Slovak Republic } \\
\text { miroslav.gal@stuba.sk }\end{array}$ \\
\hline & $\begin{array}{l}\text { Guzel Ziyatdinova, Assoc. Prof. } \\
\text { Alexander Butlerov Institute of Chemistry, Kazan Federal University, Republic of } \\
\text { Tatarstan } \\
\text { ziyatdinovag@mail.ru }\end{array}$ \\
\hline & $\begin{array}{l}\text { Jiri Barek, Prof. } \\
\text { Charles University, Prague, Czech Republic } \\
\text { barek@natur.cuni.cz }\end{array}$ \\
\hline \multicolumn{2}{|l|}{ Opposed Reviewers: } \\
\hline Abstract: & 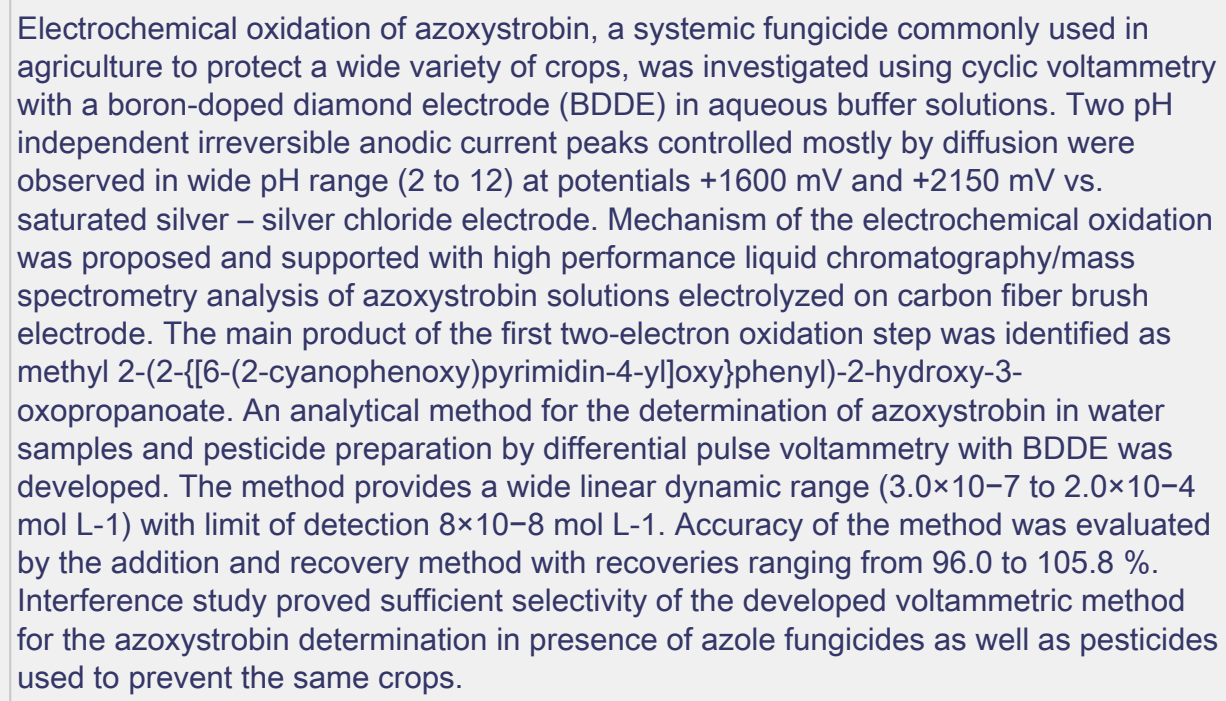 \\
\hline
\end{tabular}




\begin{tabular}{|c|c|}
\hline Author Comments: & $\begin{array}{l}\text { Prof. José M. Pingarrón } \\
\text { Editor of Electroanalysis } \\
\text { Pardubice, September 13th, } 2018 \\
\text { Dear Professor Pingarrón, } \\
\text { Enclosed please find our manuscript, entitled "Oxidation behavior of insecticide } \\
\text { azoxystrobin and its voltammetric determination using boron-doped diamond } \\
\text { electrode", by Renáta Šelešovská, Marie Herynková, Jana Skopalová, Pavlína } \\
\text { Kelíšková-Martinková, Lenka Janíková, Petr Cankaŕ, Petr Bednár̆, and Jaromíra } \\
\text { Chýlková. We participated in the "ESEAC 2018" conference on Rodos in Greece } \\
\text { during June } 2014 \text { and this paper represents our enhanced conference contribution. } \\
\text { Therefore, we would like to submit this manuscript for publication in the special issue of } \\
\text { "Electroanalysis" dedicated to this conference. } \\
\text { Many thanks for your considering the manuscript. } \\
\text { Yours sincerely, } \\
\text { Renáta Šelešovská } \\
\text { University of Pardubice } \\
\text { Studentská } 573,53210 \text { Pardubice } \\
\text { Czech Republic } \\
\text { Tel.: +420 } 466038053 \\
\text { Renata.Selesovska@upce.cz }\end{array}$ \\
\hline Section/Category: & ESEAC 2018 (Editor: Pingarrón) \\
\hline \multicolumn{2}{|l|}{ Additional Information: } \\
\hline Submitted solely to this journal? & Yes \\
\hline Has there been a previous version? & No \\
\hline
\end{tabular}


Click here to access/download Supporting Information Supplementary material_11-9-2018.docx 


\title{
Oxidation behavior of insecticide azoxystrobin and its voltammetric determination using boron-doped diamond electrode
}

\author{
Renáta Šelešovská, ${ }^{a *}$ Marie Herynková, ${ }^{a}$ Jana Skopalová, ${ }^{\mathrm{b}}$ Pavlína Kelíšková-Martinková, ${ }^{\mathrm{a}}$ \\ Lenka Janíková, ${ }^{\mathrm{a}}$ Petr Cankar̆, ${ }^{\mathrm{c}}$ Petr Bednář, ${ }^{\mathrm{b}}$ and Jaromíra Chýlkováa
}

a Institute of Environmental and Chemical Engineering, Faculty of Chemical Technology, University of Pardubice, Studentská 573, 53210 Pardubice, Czech Republic

b Department of Analytical Chemistry, Faculty of Science, Palacký University in Olomouc, 17. listopadu 12, 77146 Olomouc, Czech Republic

c Department of Organic Chemistry, Faculty of Science, Palacký University in Olomouc, 17. listopadu 12, 77146 Olomouc, Czech Republic

* e-mail: Renata.Selesovska@upce.cz

\begin{abstract}
Electrochemical oxidation of azoxystrobin, a systemic fungicide commonly used in agriculture to protect a wide variety of crops, was investigated using cyclic voltammetry with a boron-doped diamond electrode (BDDE) in aqueous buffer solutions. Two $\mathrm{pH}$ independent irreversible anodic current peaks controlled mostly by diffusion were observed in wide $\mathrm{pH}$ range ( 2 to 12 ) at potentials $+1600 \mathrm{mV}$ and $+2150 \mathrm{mV}$ vs. saturated silver - silver chloride electrode. Mechanism of the electrochemical oxidation was proposed and supported with high performance liquid chromatography/mass spectrometry analysis of azoxystrobin solutions electrolyzed on carbon fiber brush electrode. The main product of the first two-electron oxidation step was identified as methyl 2-(2-\{[6-(2-cyanophenoxy)pyrimidin-4yl]oxy\}phenyl)-2-hydroxy-3-oxopropanoate. An analytical method for the determination of azoxystrobin in water samples and pesticide preparation by differential pulse voltammetry with BDDE was developed. The method provides a wide linear dynamic range $\left(3.0 \times 10^{-7}\right.$ to $2.0 \times 10^{-4} \mathrm{~mol} \mathrm{~L}-1$ ) with limit of detection $8 \times 10^{-8} \mathrm{~mol} \mathrm{~L}^{-1}$. Accuracy of the method was evaluated by the addition and recovery method with recoveries ranging from 96.0 to $105.8 \%$. Interference study proved sufficient selectivity of the developed voltammetric method for the azoxystrobin determination in presence of azole fungicides as well as pesticides used to prevent the same crops.
\end{abstract}


Keywords: Pesticides $\bullet$ Azoxystrobine $\bullet$ Oxidation mechanism $\bullet$ Voltammetric determination $\bullet$ Boron-doped diamond electrode 


\section{Introduction}

Azoxystrobin (AS, methyl (2E)-2-(2-\{[6-(2-cyanophenoxy)pyrimidin-4-yl]oxy\}phenyl)-3methoxyacrylate, CAS: 131860-33-8), whose structural formula is shown in Scheme 1, belongs to the group of synthetic fungicides strobilurins derived from the active substances produced by wood-destroying fungi [1]. AS was placed on the market in 1996. Since then it has been registered worldwide for application to a wide variety of crops, e.g., vegetables, potatoes, cereals, oilseed rape, but also for protection of ornamental plants [2]. Its fungicidal effect is based on inhibition of mitochondrial respiration of fungi. AS blocks the electron transfer between cytochrome $\mathrm{b}$ and cytochrome $\mathrm{c} 1$ which leads to the oxidative stress in the fungus cells and prevents their growth [3-5]. Beside the positive agricultural effects, negative environmental impacts of AS as a number of other pesticide have been observed. Considering human toxicology, AS can be harmful by inhalation, can cause serious eyes damage, allergic skin reactions or respiratory irritation. Moreover, AS is highly toxic to aquatic organisms such as freshwater or marine fish and aquatic invertebrates [6]. Therefore, it is necessary to have sensitive and selective methods for its monitoring in environment and foodstuffs as well as in commercially available pesticide preparations.<smiles>CO/C=C(/C(=O)OC)c1ccccc1Oc1cc(Oc2ccccc2C#N)ncn1</smiles>

Scheme 1 Structural formula of azoxystrobin

Up to now, this pesticide has been most commonly determined by chromatographic methods. The analysis was always proceeding by separation procedure when the analyte was isolated from the matrix most often by solid phase/liquid or liquid/liquid extraction. To determine AS in various samples, specific methods using gas chromatography with an electron capture detector [7-11], high performance liquid chromatography with UV spectrophotometric [12-14] or diode array detector [15], and micellar electrokinetic chromatography with UV spectrophotometric detector [16] were described in literature. Chromatography is often combined also with mass spectrometry for the purposes of AS determination [14, 17-19]. Beside above-mentioned chromatographic methods, a flow 
injection-solid phase spectroscopic system combined with photochemically-induced fluorescence was developed for the AS determination [20] as well.

Voltammetric methods represent simple, fast, and sensitive alternative to the chromatographic methods which can allow application in portable analyzers. Moreover, these methods require usually simpler sample pretreatment. Electrochemical detection can be also connected with the chromatographic separation. However, only one paper dealing with the AS voltammetric determination was published [21]. Pacheco et al. used hanging mercury drop electrode (HMDE) and determined AS via its reduction at the potential about $-1000 \mathrm{mV}$ (vs. $\left.\mathrm{Ag} / \mathrm{AgCl}\left(3 \mathrm{~mol} \mathrm{~L}^{-1}\right)\right)$ in acidic media $(0.1 \mathrm{M} \mathrm{HCl})$. With the respect to the commonly known disadvantages of HMDE, especially the toxicity of liquid mercury (more precisely the toxicity of mercury vapors or its organometallic compounds) and mechanical instability of mercury drop, it would be more preferable to use another working electrode. Due to the fact, that several papers focused on the determination of some other strobilurin fungicides (e.g., picoxystrobin, pyraclostrobin, kresoxim-methyl, trifloxystrobin, dimoxystrobin) using borondoped diamond electrode (BDDE) have been published [22-26], this working electrode was applied also for study of the electrochemical behavior of AS and for the development of voltammetric method for its determination in the present paper. Boron-doped diamond is universal electrode material used in electroanalytical chemistry in form of thin polycrystalline films [27, 28]. It excels in mechanical, physical and electrochemical properties. The main advantages of BDDE are wide usable potential window in anodic as well as in cathodic area, low capacitive current, low noise, stable and repeatable current response, and minimal risk of passivation due to the low adsorption [29-31]. BDDE is most commonly used for determination of organic compounds by monitoring of the appropriate oxidation reactions [29, 32-38].

In the present paper, the voltammetric behavior of AS has been studied using BDDE and its oxidation reaction was firstly investigated. Oxidation mechanism was proposed based on results of controlled potential electrolysis and analysis of the generated oxidation products using ultraperformance liquid chromatography - mass spectrometry with electrospray ionization. Finally, voltammetric method for AS determination was developed and utilized for analysis of drinking and river water as well as a commercially available pesticide preparation.

\section{Experimental}

\subsection{Chemicals}


Unless otherwise indicated, all chemicals used during the experiments were of purity p.a. $0.001 \mathrm{M}$ solution of AS (Sigma-Aldrich) was prepared by dissolution of its appropriate amount in acetonitrile (Ing. Petr Švec - PENTA, Czech Republic) and stored in a refrigerator in the dark at $+4^{\circ} \mathrm{C}$. Lower concentrations were obtained daily by dilution with BrittonRobinson buffer (BRB) with the suitable $\mathrm{pH}$ value. BRB was prepared by mixing of acidic and alkaline component under the $\mathrm{pH}$-meter. Acidic component consists of $0.04 \mathrm{M}$ solution of $\mathrm{H}_{3} \mathrm{PO}_{4}, \mathrm{H}_{3} \mathrm{BO}_{3}$, and $\mathrm{CH}_{3} \mathrm{COOH}$, alkaline component was $0.2 \mathrm{M} \mathrm{NaOH}$ (all from Ing. Petr Švec - PENTA, Czech Republic). 0.1 $\mathrm{M} \mathrm{HNO}_{3}$ was diluted from $65 \%$ stock solution (Lachema, Czech Republic). $0.001 \mathrm{M}$ standard solutions of other pesticide substances (difenoconazole, cyproconazole, propiconazole, epoxiconazole, tebuconazole, triclopyr, imidacloprid, chlorpyriphos, triasulfuron, glyphosate, tribenuron; all these chemicals from Sigma-Aldrich) were prepared by dissolving of the calculated amount in the suitable solvent (deionized water (conductivity $<0.05 \mu \mathrm{S} \mathrm{cm}^{-1}$, produced by Milli-Q-Gradient, Millipore, Czech Republic), methanol, acetonitrile (both Ing. Petr Švec - PENTA, Czech Republic) with the respect to the individual solubility. Commercially available pesticide preparation "Ortiva" was produced by the company Syngenta Czech, Czech Republic. Acetonitrile $(\geq 99.9 \%$, gradient grade for HPLC, VWR Chemicals), acetic acid (99.7\%) and ammonium acetate (for HPLC, both Sigma-Aldrich) were used for controlled potential electrolysis and HPLC/MS analysis.

\subsection{Instrumentation}

Voltammetric measurements were carried out using Eco-Tribo Polarograph (Polaro-Sensors, Czech Republic) equipped with software POLAR.PRO 5.1 [39]. Measurements were performed in three-electrode set up where BDDE (Windsor Scientific, Great Britain) served as a working electrode, saturated silver-silver chloride electrode $(\mathrm{Ag} / \mathrm{AgCl}(\mathrm{KCl}$, sat.)) as a reference and platinum wire as an auxiliary electrode (both Monokrystaly, Czech Republic). A potentiostat Autolab PGSTAT128N (Metrohm Autolab, Nederland) was employed for controlled potential electrolysis. Three-electrode system consisted of a working carbon fiber brush electrode (CFBE) [40], reference saturated calomel electrode (SCE) and platinum auxiliary electrode placed in a cathodic compartment separated by a glass frit. Electrolyzed solutions were analyzed using Acquity UPLC system (Waters, USA) with PDA detector and mass spectrometric detector (QDA) equipped with heated electrospray ionization (HESI) and quadrupole analyzer. The pH-meter Accumet AB150 (Fisher Scientific, Czech Republic) was 
used for measurement of $\mathrm{pH}$ values and the ultrasonic bath Bandelin Sonorex (Schalltec $\mathrm{GmbH}$, Germany) served for facilitating dissolution of pesticides.

\subsection{Procedures}

\subsubsection{Voltammetric measurements}

At the beginning of the work before the first measurement, BDDE was subjected to the electrochemical activation using cyclic voltammetry (CV). This procedure consists from 20 cycles in potential range from initial potential $\left(E_{\text {in }}\right)-1750 \mathrm{mV}$ to switching potential $\left(E_{\text {switch }}\right)+2500 \mathrm{mV}$ in an milieu of used electrolyte. No further electrode manipulation between measurements or surface regeneration has been included. Due to the easy oxidation of the BDDE surface even in the air, it can be assumed that the measurements proceeded on the O-terminated surface of the electrode.

Voltammetric behavior of AS on a BDDE was investigated using CV and the dependences on $\mathrm{pH}$ as well on scan rate $(v)$ were obtained. Cyclic voltammograms were measured from $E_{\text {in }}$ $-1500 \mathrm{mV}$ to $E_{\text {switch }}+2500 \mathrm{mV}$ at $v 100 \mathrm{mV} \mathrm{s}^{-1}$. Testing the influence of $v$, this parameter was changed in the range $25-400 \mathrm{mV} \mathrm{s}^{-1}$. Differential pulse voltammetry (DPV) was utilized for AS determination and BRB of $\mathrm{pH} 2.0$ was chosen as the most suitable medium. Optimized parameters of DPV were as follows: $E_{\text {in }} 0 \mathrm{mV}$, final potential $\left(E_{\mathrm{fin}}\right)+2100 \mathrm{mV}, v 20 \mathrm{mV} \mathrm{s}{ }^{-1}$, pulse height $+60 \mathrm{mV}$, and pulse width $30 \mathrm{~ms}$. Peak heights were evaluated from the base line inserted as a straight line connecting the minima before and after the peak. In case of low AS concentrations, baseline correction in software POLAR.PRO 5.1 was applied to improve peak evaluability. The resulting voltammetric curves as well as $\mathrm{pH}$, scan rate and concentration dependencies were processed in MS Excel 2010 (Microsoft, USA). Parameters of calibration curves with appropriate confidence intervals at a significance level of $\alpha=0.05$ were calculated using OriginPro 9 (Origin Lab Corporation, USA). The detection limit (LOD) was calculated as the $3 \times$ standard deviation of the intercept divided by the slope and the limit of quantification (LOQ) as the 10x standard deviation of the intercept divided by the slope.

\subsubsection{Controlled potential electrolysis and HPLC/MS analysis}

Before electrolysis, the working CFBE was successively cleaned in a ultrasonic bath with acetonitrile and deionized water (for 5 minutes each) and electrochemically pretreated in 0.1 $\mathrm{M} \mathrm{H}_{2} \mathrm{SO}_{4}$ by applying 50 repetitive potential cycles in the range of $-1700 \mathrm{mV}$ to $2000 \mathrm{mV}$ (vs. $\mathrm{SCE}$ ). Finally, the electrode was carefully rinsed with deionized water. Bulk electrolysis of AS solution $\left(1 \times 10^{-3} \mathrm{M}\right)$ was performed in $0.1 \mathrm{M} \mathrm{CH}_{3} \mathrm{COOH}$ with acetonitrile $(1: 1, \mathrm{v} / \mathrm{v})$ at the 
potentials of $1600 \mathrm{mV}$ and $2000 \mathrm{mV}$ (SCE) for $30 \mathrm{~min}$ on an electromagnetic stirrer. Total volume of the electrolyzed sample was $4 \mathrm{~mL}$. Cathodic compartment of the electrolytic cell with auxiliary electrode was filled with the mixture of $0.1 \mathrm{M} \mathrm{CH}_{3} \mathrm{COOH}$ and acetonitrile (1:1, v/v). Electrolyzed samples were directly analysed using HPLC/MS. Simultaneously, unelectrolyzed solution of AS $\left(1 \times 10^{-3} \mathrm{M}\right)$ in $0.1 \mathrm{M} \mathrm{CH}_{3} \mathrm{COOH}$ with acetonitrile $(1: 1, \mathrm{v} / \mathrm{v})$ was analysed for comparison. Chromatographic separation was performed on XSelect HSS T3 column $(3 \mathrm{~mm} \times 50 \mathrm{~mm}, 2.5 \mu \mathrm{m}$, Waters $)$ at $25{ }^{\circ} \mathrm{C}$. Mobile phase consisted of $0.01 \mathrm{M}$ ammonium acetate in water (solvent $\mathrm{A}$ ) and a mixture of acetonitrile and water 9:1, v/v (solvent B). Gradient elution was performed: 0-4.5 min (78-12\% A), 4.5-5 min (12\% A) with flow rate $0.6 \mathrm{~mL} \mathrm{~min}^{-1}$. After the analysis the column was equilibrated to the initial ratio of both mobile phases for $2 \mathrm{~min}$. The injection volume was $5 \mu \mathrm{L}$. Mass spectrometric conditions were as follows: positive electrospray mode, capillary voltage $0.8 \mathrm{kV}$, cone $30 \mathrm{~V}$, source temperature $120{ }^{\circ} \mathrm{C}$ and heated probe temperature $600{ }^{\circ} \mathrm{C}$. The acquired mass range was $\mathrm{m} / \mathrm{z}$ 60 - 800. Data were processed using MassLynx 4.1 software (Waters).

\subsubsection{Real samples analysis}

Drinking water was sampled from water supply in the laboratory of University of Pardubice. River water originated from the river Chrudimka and it was taken in Slatiňany. Until the time of analysis, the sample was placed in the refrigerator. Both samples were analyzed by the same procedure. $13 \mathrm{~mL}$ of water sample spiked with standard solution of AS on the required concentration level was dosed into the polarographic cell together with $2 \mathrm{~mL}$ of $\mathrm{BRB}(\mathrm{pH}$ 2.0). Several concentration dependencies were measured and statistical parameters (LOD, LOQ) were calculated. Repeatability of AS determination was tested at the analyte concentration $5.0 \times 10^{-6} \mathrm{M}$ using standard addition method with consecutive additions of $75 \mu \mathrm{L}$ of $0.001 \mathrm{M}$ standard solution of AS. Every determination was $5 \times$ repeated and the average value with the respective confidence interval, recovery and relative standard deviation $(R S D)$ were calculated.

Analyzed pesticide preparation "Ortiva" intended especially to protect vegetables against fungal disease is supplied as a suspension concentrate with the declared AS content $250 \mathrm{~g} \mathrm{~L}^{-1}$. The solution with the AS concentration about $0.001 \mathrm{M}$ (calculated from the content declared by producer) was prepared by dissolution of the appropriate volume of preparation in acetonitrile applying ultrasonic bath. For the following analysis, $75 \mu \mathrm{L}$ of the prepared solution was added into the polarographic cell to the $15 \mathrm{~mL}$ of BRB ( $\mathrm{pH} 2.0$ ). The analysis 
was performed and evaluated using standard addition method in the same way as in case of water samples.

\section{Results and discussion}

\subsection{Voltammetric behavior of azoxystrobine}

\subsubsection{Dependence on $\mathrm{pH}$}

First experiments were focused on voltammetric behavior of AS in dependence on $\mathrm{pH}$ of the supporting electrolyte. As it can be seen from the cyclic voltammograms presented in Fig. 1A, AS provided two oxidation signals at the potentials $+1600 \mathrm{mV}$ and $+2150 \mathrm{mV}$ in BRB of $\mathrm{pH}$ 2.0. No corresponding reduction peaks were observed on cathodic branch of voltammograms, which indicated irreversibility of the observed electrode reaction. The influence of $\mathrm{pH}$ on the shape and position of AS peaks is illustrated in Fig. 1B. Except for $0.1 \mathrm{M} \mathrm{HCl}$, where only peak 1 was registered, both oxidation responses were observed in the whole tested $\mathrm{pH}$ range 2.0-12.0. Because of the independency of the peaks position on $\mathrm{pH}$ of the media, it can be assumed that the protons do not participate in the ongoing reaction. The highest and the bestevaluable signals were observed in BRB of $\mathrm{pH}$ 2.0. Therefore, this medium was used for all subsequent experiments.

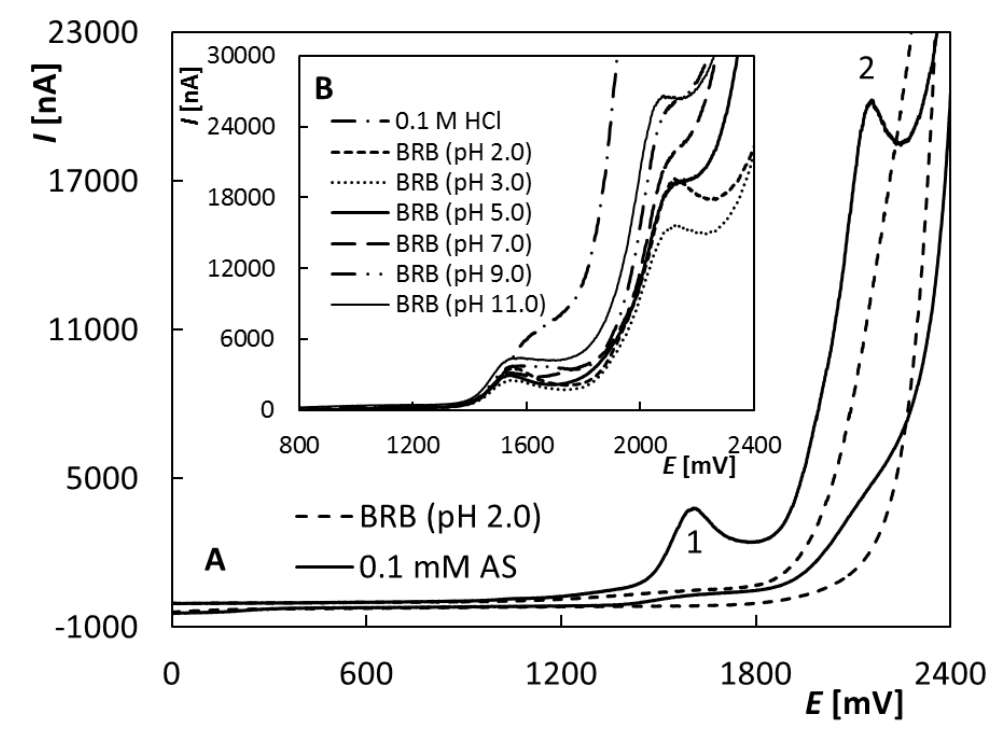

Fig. $1 \mathrm{~A}$ - Cyclic voltammograms in absence and presence of $0.1 \mathrm{mM}$ AS in BRB (pH 2.0) obtained on BDDE, B - anodic parts of cyclic voltammograms of $0.1 \mathrm{mM}$ AS in dependence on $\mathrm{pH}\left(0.1 \mathrm{M} \mathrm{HCl}, \mathrm{BRB}(\mathrm{pH} 2-11) ; E_{\text {in }}=E_{\text {fin }}=-1500 \mathrm{mV}, E_{\text {switch }}=+2500 \mathrm{mV}, v=\right.$ $100 \mathrm{mV} \mathrm{s}^{-1}$.

\subsubsection{Dependence on scan rate}


The voltammetric behavior of AS in dependence on $v$ was registered in the range from 25 to $400 \mathrm{mV} \mathrm{s}^{-1}$. It is evident from Fig. 2A that both AS peaks increased with the rising $v$. Both maxima on curves were shifted to the more positive potential values, which corresponded to the above-mentioned irreversibility of the electrode reaction. Inserted Fig. 2B shows that the course of the dependences of peak height $\left(I_{\mathrm{p}}\right)$ on $v$ is not linear, as opposed to the dependences of $I_{\mathrm{p}}$ on $v^{1 / 2}$ (Fig. 2C, D) described by the equations (1) for peak 1 and (2) for peak 2 with the acceptable correlation coefficients. The result suggested to the diffusion-controlled electrode reaction. This conclusion was confirmed also by the logarithmic dependences $\left(\log \left(I_{\mathrm{p}}\right) \_\log (v)\right)$ described by equations ( 3 , peak 1$)$ and (4, peak 2 ) which provided the slope values close to the theoretical one 0.5. However, the value of 0.5 did not lie in the obtained confident intervals of the slopes in both cases but it was lower $((0.4071 \pm 0.0083)$ and $(0.4411 \pm 0.0078))$. Therefore, it was possible to conclude that the electrode reaction was controlled mainly by diffusion with a contribution of kinetics.

$$
\begin{aligned}
& I_{\mathrm{p}}[\mathrm{nA}]=(107.1 \pm 2.6) v^{1 / 2}\left[\left(\mathrm{mV} \mathrm{s}^{-1}\right)^{1 / 2}\right]+(331 \pm 38), r=0.9959 \\
& I_{\mathrm{p}}[\mathrm{nA}]=(445.3 \pm 9.7) v^{1 / 2}\left[\left(\mathrm{mV} \mathrm{s}^{-1}\right)^{1 / 2}\right]+(861 \pm 141), r=0.9967 \\
& \log \left(I_{\mathrm{p}}[\mathrm{nA}]\right)=(0.4071 \pm 0.0083) \log \left(v\left[\left(\mathrm{mV} \mathrm{s}^{-1}\right)\right]\right)+(2.334 \pm 0.019), r=0.9971 \\
& \log \left(I_{\mathrm{p}}[\mathrm{nA}]\right)=(0.4411 \pm 0.0078) \log \left(v\left[\left(\mathrm{mV} \mathrm{s}^{-1}\right)\right]\right)+(2.843 \pm 0.018), r=0.9977
\end{aligned}
$$




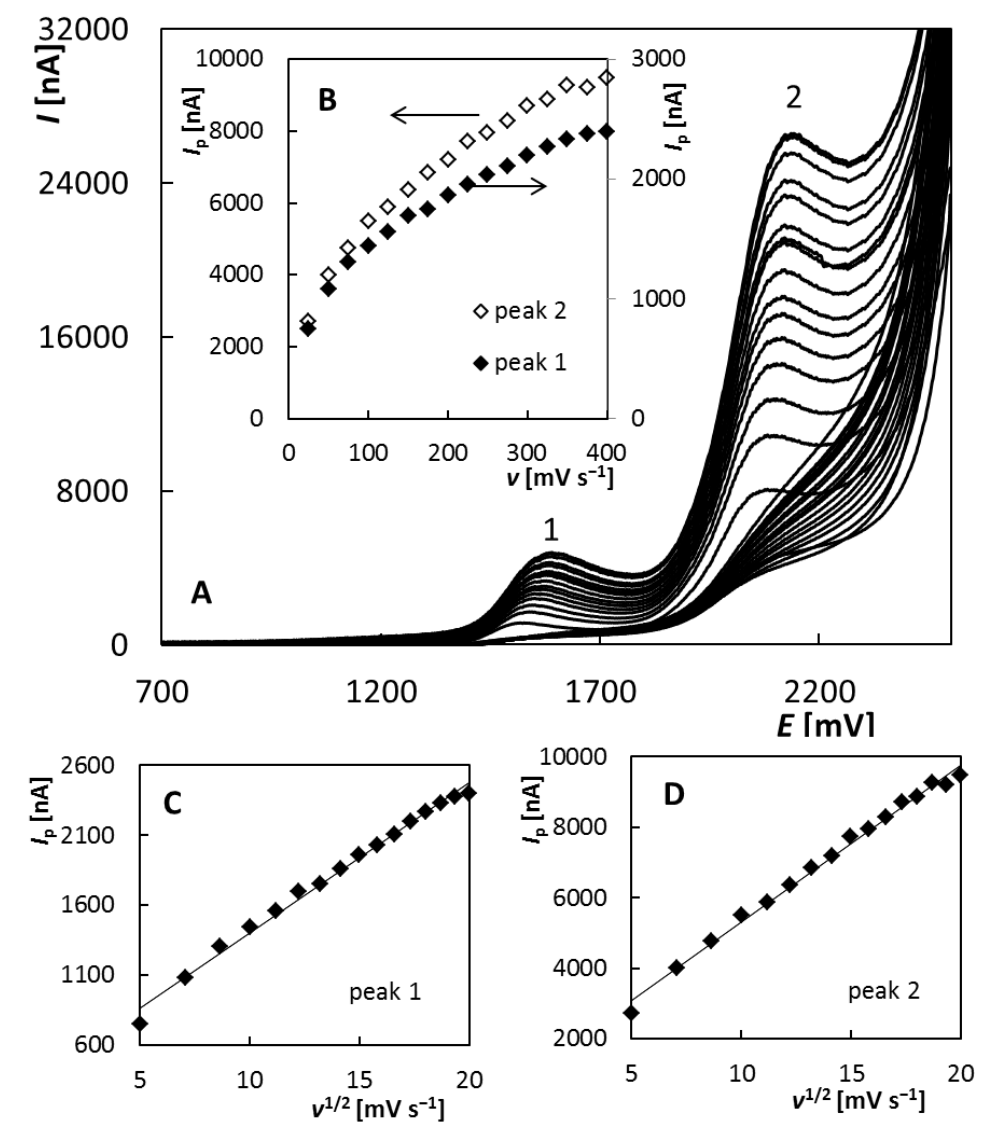

Fig. 2 A - Cyclic voltammograms of $0.1 \mathrm{mM}$ AS in BRB (pH 2.0) obtained on BDDE at various scan rates, B - dependences of $I_{\mathrm{p}}$ on $v$ for both peaks, $\mathrm{C}-$ dependence of $I_{\mathrm{p}}$ on $v^{1 / 2}$ for peak $1, \mathrm{D}-$ dependence of $I_{\mathrm{p}}$ on $v^{1 / 2}$ for peak $2 ; E_{\text {in }}=E_{\text {fin }}=0 \mathrm{mV}, E_{\text {switch }}=+2500 \mathrm{mV}, v=25$ $400 \mathrm{mV} \mathrm{s}^{-1}$.

\subsection{Oxidation mechanism of azoxystrobine}

\subsubsection{Number of electrons involved in electrode reaction}

To determine number of electrons transferred in the first oxidation step, which was further used for analytical applications, linear sweep voltammograms were processed by convolutive technique [41]. The procedure was applied to the voltammetric $I-E$ data obtained under the experimental conditions specified in the Fig. 1A caption. Transformation of the data to the dimensionless form was performed using the value of the diffusion coefficient $D$ estimated from the Wilke-Chang equation (5) [42]:

$D=7.4 \times 10^{-8} \frac{T(x M)^{1 / 2}}{\eta V^{0.6}}$,

where $T$ is thermodynamic temperature, $\eta$ is viscosity, $x$ and $M$ are association parameter and molar weight of the solvent, respectively, and $V$ represents molar volume of the solute. For the used experimental conditions $T=298.15 \mathrm{~K}$, viscosity of water $\eta=0.89 \mathrm{cP}$ [43], 
association parameter of water $x=2.6$, molar weight of water $M=18.015 \mathrm{~g} \mathrm{~mol}^{-1}$ and molar volume of AS $V=300.1 \pm 5.0 \mathrm{~cm}^{3}$ calculated using ACD/ChemSketch software, the value of diffusion coefficient $D=5.5 \times 10^{-6} \mathrm{~cm}^{2} \mathrm{~s}^{-1}$ was obtained. Semi-integration of the dimensionless data provided S-shaped curve (see Fig. S1 in Supplementary materials), the height of which corresponded to the number of transferred electrons $n=2.1$. Therefore, the first oxidation step of azoxystrobin is a two-electron process. The attempt to determine the number of electrons using controlled potential coulometry was not successful due to non-exponential course of the recorded $I$ - $t$ curves that was caused probably by side electrochemical reactions.

\subsubsection{Controlled potential electrolysis and HPLC/MS analysis of oxidation products}

To understand electrode reactions proceeding during the analytically usable first step of azoxystrobin oxidation, $1 \mathrm{mM}$ solution of pesticide was electrolysed under controlled potential conditions. The electrolysis was performed on a large surface carbon fiber brush electrode to achieve high efficiency of azoxystrobin conversion. Acetic acid solution (0.2 M) mixed with acetonitrile $(1: 1, \mathrm{v} / \mathrm{v})$ was used as a suitable medium for electrolysis to keep AS dissolved in a solution and to study the electrochemical oxidation of AS under acidic conditions utilized later for analytical purposes. Potential values for the bulk oxidation were selected at the maximum of the first voltammetric peak $(1600 \mathrm{mV})$ and at the foot of the second peak $(2000 \mathrm{mV})$.

For comparison, HPLC/MS analysis of the unelectrolyzed AS solution was performed providing a single peak with retention time $t_{\mathrm{r}}=4.13 \mathrm{~min}$ (Fig. S2 in Supplementary information file). Mass spectrum of AS (Supplementary information, Fig. S3) rendered an ion $[\mathrm{M}+\mathrm{H}]^{+}$at $\mathrm{m} / \mathrm{z} 404$ and fragment ions at $\mathrm{m} / \mathrm{z} 372$ (loss of $\mathrm{CH}_{3} \mathrm{OH}$ from the side methoxy group) and at $\mathrm{m} / \mathrm{z} 344$ with lower intensity (subsequent loss of $\mathrm{CO}$ ). The spectrum corresponds to those reported in the literature, e.g. [44].

Chromatogram of the AS solution electrolyzed at $1600 \mathrm{mV}$ revealed a new peak with $t_{\mathrm{r}}=$ $2.54 \mathrm{~min}$ and ion $[\mathrm{M}+\mathrm{H}]^{+}$at $\mathrm{m} / z, 406$ of the main oxidation product. Short retention time suggests higher polarity of this product compared to AS. Mass spectrum of the product (Fig. $3 \mathrm{~A}$ ) rendered fragment ions at $\mathrm{m} / z 388$ (loss of $\mathrm{H}_{2} \mathrm{O}$ ) and $\mathrm{m} / z 360$ (subsequent loss of CO) suggesting presence of a hydroxyl and a carbonyl group in the structure of the oxidation product. A fragment ion at $\mathrm{m} / \mathrm{z}, 214$ corresponds to the protonated 2-[(6-hydroxypyrimidin-4yl)oxy]benzonitrile proving this part of the AS molecule remained intact. It appears that the oxidation of AS proceeds at the vinyl ether moiety resulting in respective methyl 2-hydroxy3-oxopropanoate (see the structure in Fig. 3A). 

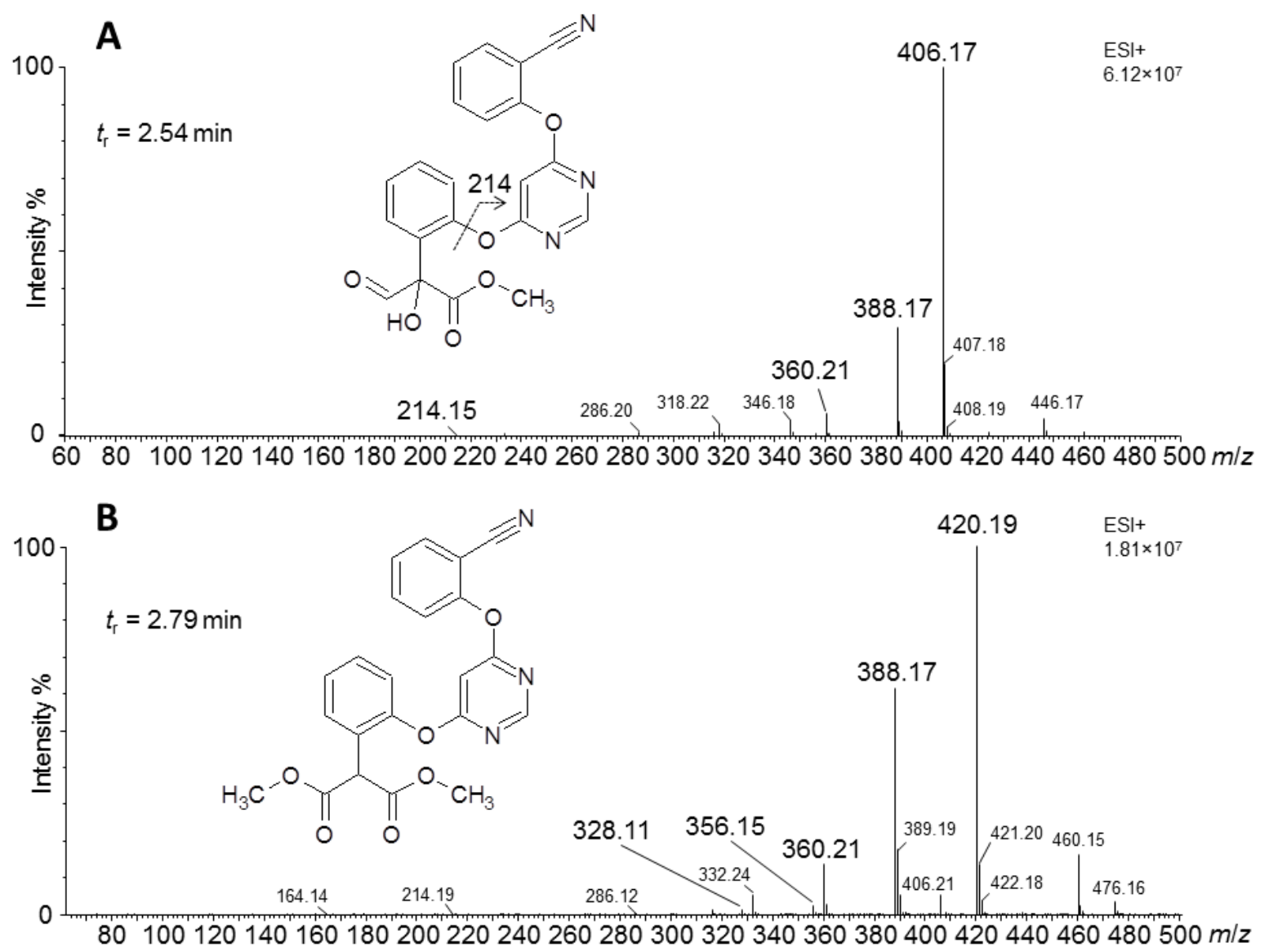

Fig. 3 Mass spectra of extracted ions $m / z 406$ (A) and $m / z 420$ (B) of AS oxidation products acquired from AS solution ( $1 \mathrm{mM}$ ) electrolyzed at $1600 \mathrm{mV}$ (A) and $2000 \mathrm{mV}$ (B) for $30 \mathrm{~min}$ on the carbon fiber brush electrode in the mixture of $0.1 \mathrm{M} \mathrm{CH}_{3} \mathrm{COOH}$ and acetonitrile 1:1, v/v after chromatographic separation.

HPLC/MS analysis of AS solution oxidized at potential of $2000 \mathrm{mV}$ provided signals of more products. Besides the most abundant peak of the main product with $m / z$ 406, a peak with $t_{\mathrm{r}}=2.78$ and $[\mathrm{M}+\mathrm{H}]^{+}$at $\mathrm{m} / \mathrm{z} 420$ was detected. Mass spectrum of this product (Fig. 3B) provides fragment ions at $\mathrm{m} / \mathrm{z} 388$ (loss of $\mathrm{CH}_{3} \mathrm{OH}$ ), $\mathrm{m} / \mathrm{z} 360$ (subsequent loss of $\mathrm{CO}$ ), $\mathrm{m} / \mathrm{z} 356$ (loss of $\mathrm{CH}_{3} \mathrm{OH}$ from the ion $\mathrm{m} / \mathrm{z}$ 388) and $\mathrm{m} / \mathrm{z}, 328$ (subsequent loss of $\mathrm{CO}$ from the ion $\mathrm{m} / \mathrm{z}$ 356). Similarly to the fragmentation of the main product, presence of fragment ion at $\mathrm{m} / \mathrm{z} 214$ corresponding with protonated 2-[(6-hydroxypyrimidin-4-yl)oxy]benzonitrile implies that the oxidation does not occur on the part of molecule containing benzonitrile and pyrimidine moieties. Based on the fragmentation, the presence of dimethyl malonate structure in the oxidation product was proposed (see Fig. 3B).

Besides the above discussed oxidation products another two were formed (i.e. those with $t_{\mathrm{r}}$ $=3.08 \mathrm{~min}$ and $4.23 \mathrm{~min}$, see Fig. S2 in the Supplementary information file). However, their 
structure was not revealed based on the available data. The presence of the main product $\left(t_{\mathrm{r}}=\right.$ $2.54 \mathrm{~min})$ and the second eluting product $\left(t_{\mathrm{r}}=2.78 \mathrm{~min}\right)$ point out that the oxidation processes are connected with the vinyl ether moiety of the AS molecule as discussed in detail in the next paragraph.

\subsubsection{Oxidation mechanism}

Based on the voltammetric data and the results from HPLC/MS analysis of the AS solutions electrolysed under controlled potentials at $1600 \mathrm{mV}$ and $2000 \mathrm{mV}$, the pathway for the first oxidation step of AS was proposed (Scheme 2). The electrochemical reaction of AS (1) starts with an electron transfer from the oxygen of the vinyl ether moiety. Resulting benzyl radical (2) reacts with a molecule of water to form hemiacetal benzyl radical (3). This intermediate is predominantly hydrolysed to corresponding aldehyde benzyl radical (4), which undergoes one-electron oxidation to benzyl cathion (5). Reaction with water results in hydroxyl ester (6), which is the main oxidation product of the first oxidation step at lower potential of $1600 \mathrm{mV}$. Further, if potential is increased to $2000 \mathrm{mV}$, competitive oxidation of benzyl radical into benzyl cathion (7) occurs. Then hydrogen elimination leads to enol (8) which is stabilized by tautomerism into corresponding dimethyl malonate (9).

It can be assumed that the main oxidation product (6) possessing an aldehyde and a hydroxyl group can be further oxidized at the higher potential of the second voltammetric peak. However, the study of this second oxidation step has not been the subject of this work. 
<smiles>[R]Oc1ccccc1C(C(=O)OC)C(O)OC</smiles>

$[\mathrm{M}+\mathrm{H}]^{+}=404$

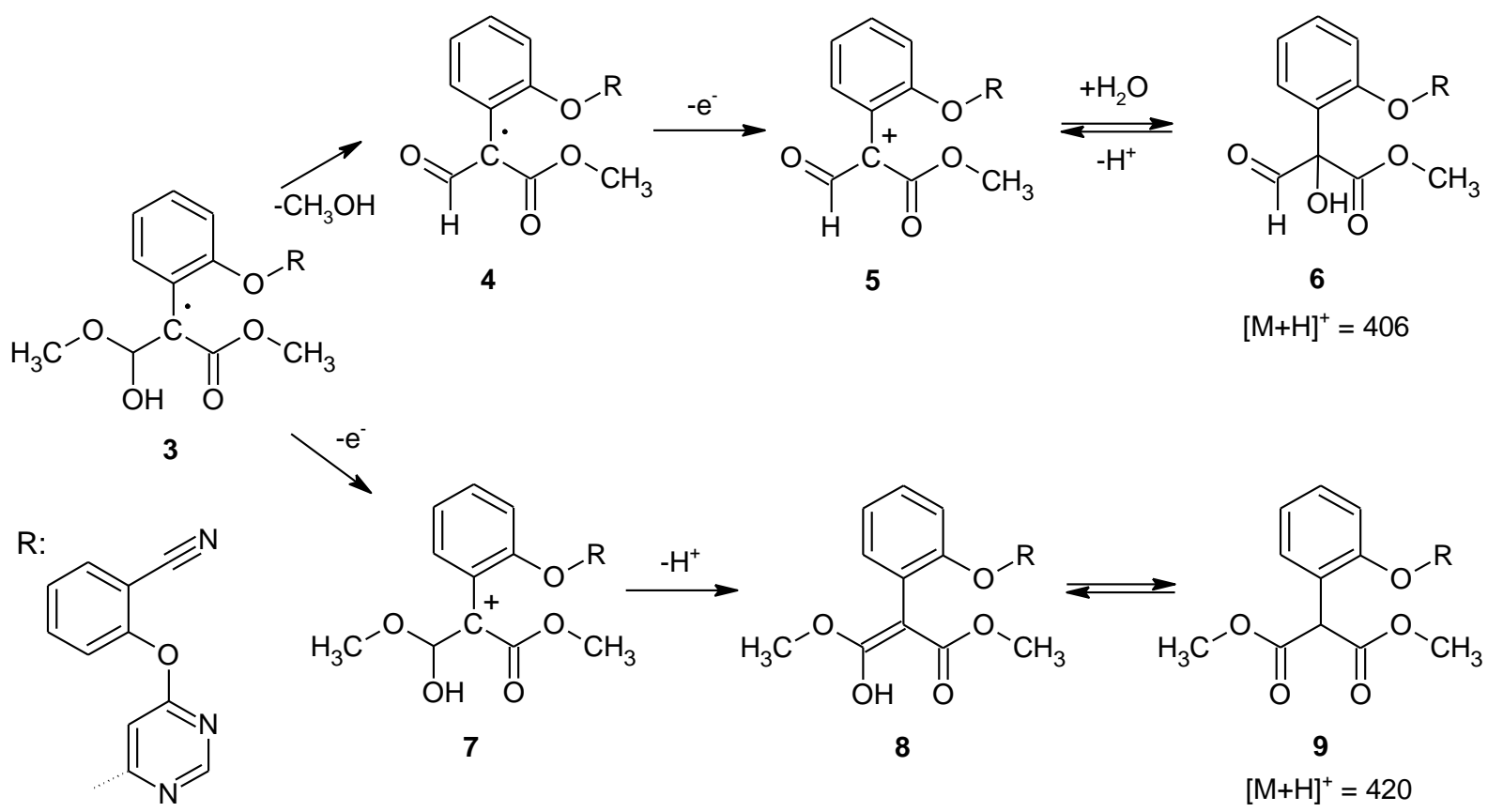

Scheme 2 Proposed mechanism of the first step of electrochemical oxidation of azoxystrobin

\subsection{Analytical performance}

For the analytical application, the first oxidation signal of AS was used due to its better position and related better evaluability. The DPV method in BRB of $\mathrm{pH} 2$ was utilized for AS determination using BDDE with respect to its good sensitivity. Initially, the conditions of BDDE pretreatment leading to improve its electrochemical properties were tested and parameters of DPV like scan rate, pulse height, and pulse width were optimized.

According to the literature [29, 30], the BDDE can be used with O-terminated or $\mathrm{H}$ terminated electrode surface which can be obtained by insertion of positive or negative pretreatment potential $\left(E_{\mathrm{pre}}\right)$ for a particular pretreatment time $\left(t_{\mathrm{pre}}\right)$. Some authors [45] recommend the polishing of the electrode on alumina before measurements. In case of our study, four different procedures were applied before AS analysis. The obtained voltammograms of $10 \mu \mathrm{M}$ AS oxidation responses are shown in Fig. 4A. The first procedure, which was applied also in previously described experiments, consisted of 20 cyclic voltammograms in potential range from $E_{\mathrm{in}}-1750 \mathrm{mV}$ to $E_{\text {switch }}+2500 \mathrm{mV}$ in BRB (pH 2). 
The second one was cathodic pretreatment under the potential $-1750 \mathrm{mV}$ sustained for $300 \mathrm{~s}$. The anodic pretreatment was tested in the potential range from +2000 to $+2500 \mathrm{mV}$ and the best effect was obtained with $E_{\text {pre }}+2300 \mathrm{mV}\left(t_{\text {pre }}=300 \mathrm{~s}\right)$. The polishing of the electrode surface on alumina followed by rinsing with distilled water was the last applied practice. It is evident from the Fig. 4A, that the observed peak 1 provides the best shape and the highest $I_{\mathrm{p}}$ (Fig. 4B) using CV preatreatment. On the other hand, the worst result was achieved after the polishing, which led to the increasing of the background and narrowing of the potential window. These effects negatively influenced the evaluability of AS signal. Accordingly, cyclic voltammograms were applied as pretreatment procedure for all next experiments. In addition, it was found that insertion of this procedure only once a day (before starting of the first analysis) was sufficient and no further cleaning or regeneration step was necessary. This conclusion was verified by 11 repeated measurement of $5 \mu \mathrm{M}$ AS, evaluation of corresponding $I_{\mathrm{p}}$ values and calculation of $R S D$. Its value $(0.47 \%)$ suggested very good repeatability of measurements under the above-mentioned conditions.

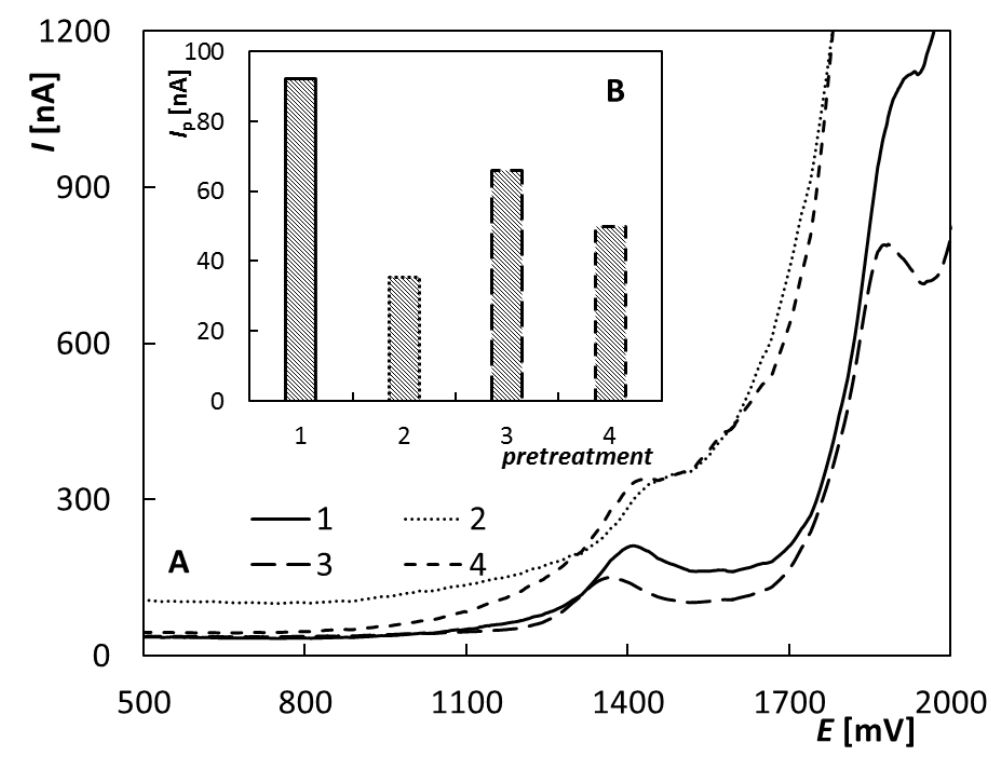

Fig. $4 \mathrm{~A}$ - DP voltammograms of $10 \mu \mathrm{M}$ AS in BRB (pH 2.0) obtained on BDDE after different pretreatment procedures, $\mathrm{B}-$ dependence of $I_{\mathrm{p}}$ on pretreatment procedure; $E_{\mathrm{in}}=$ $0 \mathrm{mV}, E_{\mathrm{fin}}=+2500 \mathrm{mV}, v=20 \mathrm{mV} \mathrm{s}^{-1}$, pulse height $=+50 \mathrm{mV}$, pulse width $=50 \mathrm{~ms}$; pretreatment procedures: 1 - cycling $\left(\mathrm{CV}, 20\right.$ cycles, $E_{\text {in }}=E_{\text {fin }}=-1750 \mathrm{mV}, E_{\text {switch }}=$ $+2500 \mathrm{mV}), 2-$ cathodic pretreatment $\left(E_{\text {pre }}=-2000 \mathrm{mV}, t_{\text {pre }}=300 \mathrm{~s}\right), 3-$ anodic pretreatment $\left(E_{\text {pre }}=+2300 \mathrm{mV}, t_{\text {pre }}=300 \mathrm{~s}\right), 4-$ polishing. 
Parameters of DPV were optimized through the analysis of $5 \mu \mathrm{M}$ solution of AS in BRB $\left(\mathrm{pH}\right.$ 2). The scan rate was tested in the range from 5 to $100 \mathrm{mV} \mathrm{s}^{-1}$ (other parameters were constant: pulse height $+50 \mathrm{mV}$, pulse width $50 \mathrm{~ms}$ ). The value of $I_{\mathrm{p}}$ increased linearly with the increasing $v$ to approximately $20 \mathrm{mV} \mathrm{s}^{-1}$ and then the growth slowed. Deformation of the peak shape and irregularly fluctuation was observed above $40 \mathrm{mV} \mathrm{s}^{-1}$. The value of $20 \mathrm{mV} \mathrm{s}^{-1}$ was applied for all following measurements. The influence of pulse height was tested between +10 and $+100 \mathrm{mV}\left(v=20 \mathrm{mV} \mathrm{s}^{-1}\right.$, pulse width $50 \mathrm{~ms}$ ). Again, $I_{\mathrm{p}}$ increased linearly with the increasing peak height, up to $+70 \mathrm{mV}$. At higher values, the increase slowed down and the signal became wider. The peak height of $+60 \mathrm{mV}$ was set for next experiments. The pulse width was tested in range from 10 to $100 \mathrm{~ms}\left(v=20 \mathrm{mV} \mathrm{s}^{-1}\right.$, pulse height $\left.+60 \mathrm{mV}\right)$. Rapid decrease of AS peak with the increasing of pulse width was observed up to $40 \mathrm{mV}$ and then $I_{\mathrm{p}}$ did not change significantly. The value $30 \mathrm{~ms}$ was applied, which practically means $30 \mathrm{~ms}$ pulse duration before next $20 \mathrm{~ms}$ of current reading.

\subsection{Determination of azoxystrobine}

\subsubsection{Analysis of model solutions}

DPV with optimized parameters in connection with BDDE was applied for analysis of model solutions containing AS. A number of concentration dependences of AS in BRB (pH 2) was measured and basic statistical parameters were determined. An example of such dependence in the range from $5.0 \times 10^{-7}$ to $1.55 \times 10^{-4} \mathrm{M}$ is shown in Fig. 5 and can be described by the following equation (6) with the appropriate correlation coefficient. From this equation, $L O D$ was calculated as $8.4 \times 10^{-8} \mathrm{M}$ and $L O Q$ as $2.8 \times 10^{-7} \mathrm{M}$, respectively. Based on these results, the linear dynamic range $(L D R)$ of the proposed method was established in the similar extend $\left(3.0 \times 10^{-7}\right.$ to $\left.2.0 \times 10^{-4}\right)$ which represents very wide usable range of concentrations.

$I_{\mathrm{p}}[\mathrm{nA}]=(13.920 \pm 0.099) c[\mu \mathrm{M}]+(-2.19 \pm 0.39), r=0,9998$

The repeatability of AS determination was verified through the analysis of model solutions with two different AS concentrations, namely $5.0 \times 10^{-6}$ and $1.0 \times 10^{-6} \mathrm{M}$. Standard addition method was applied, each determination was $5 \times$ repeated and the obtained results, as the average concentrations with relevant confident intervals, recoveries, and RSDs, are summarized in Table 1. It is evident that the concentration measurement is accurate and precise. The values of $R S D<4 \%$ suggest very good repeatability of AS determination using BDDE. An example of AS model solution analysis is placed in Fig. 6 together with graphical evaluation of standard addition method. 


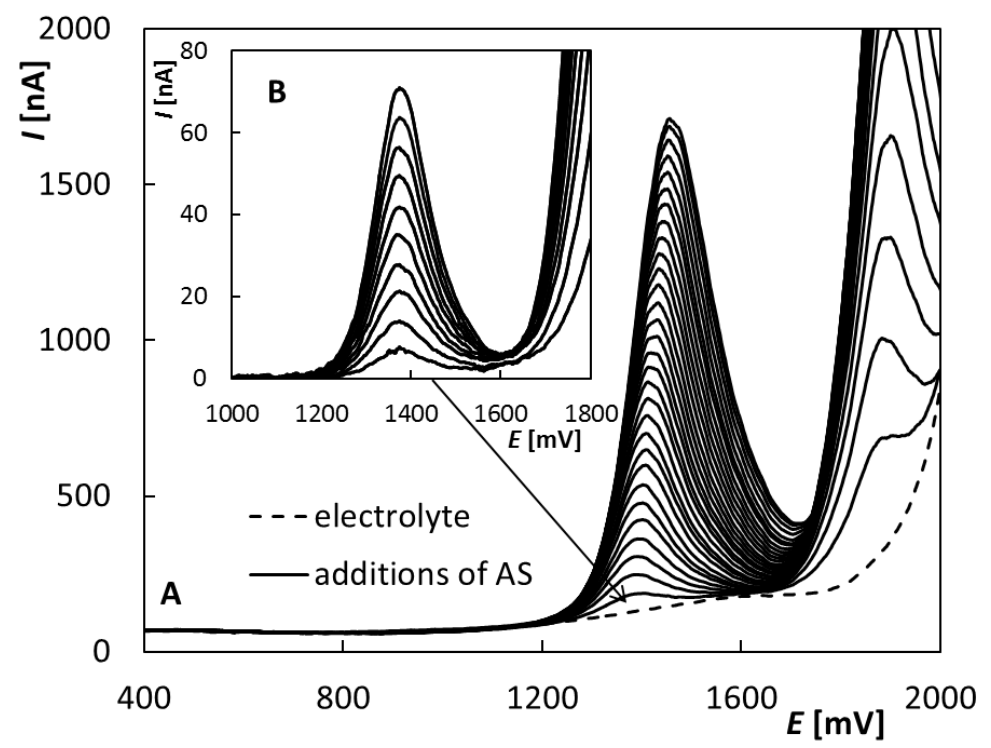

Fig. 5 A - DP voltammograms of AS in BRB (pH 2.0) obtained on BDDE in dependence on concentration $\left(c_{\mathrm{AS}}=5.00 \times 10^{-6}-1.55 \times 10^{-4} \mathrm{M}\right), \mathrm{B}-\mathrm{DP}$ voltammograms of AS after baseline correction in $\mathrm{BRB}(\mathrm{pH} 2.0)$ obtained on BDDE in dependence on concentration $\left(c_{\mathrm{AS}}=\right.$ $\left.5.0 \times 10^{-7}-5.0 \times 10^{-6} \mathrm{M}\right) ; E_{\text {in }}=0 \mathrm{mV}, E_{\text {fin }}=+2500 \mathrm{mV}, v=20 \mathrm{mV} \mathrm{s}^{-1}$, pulse height $=+60 \mathrm{mV}$, pulse width $=30 \mathrm{~ms}$.

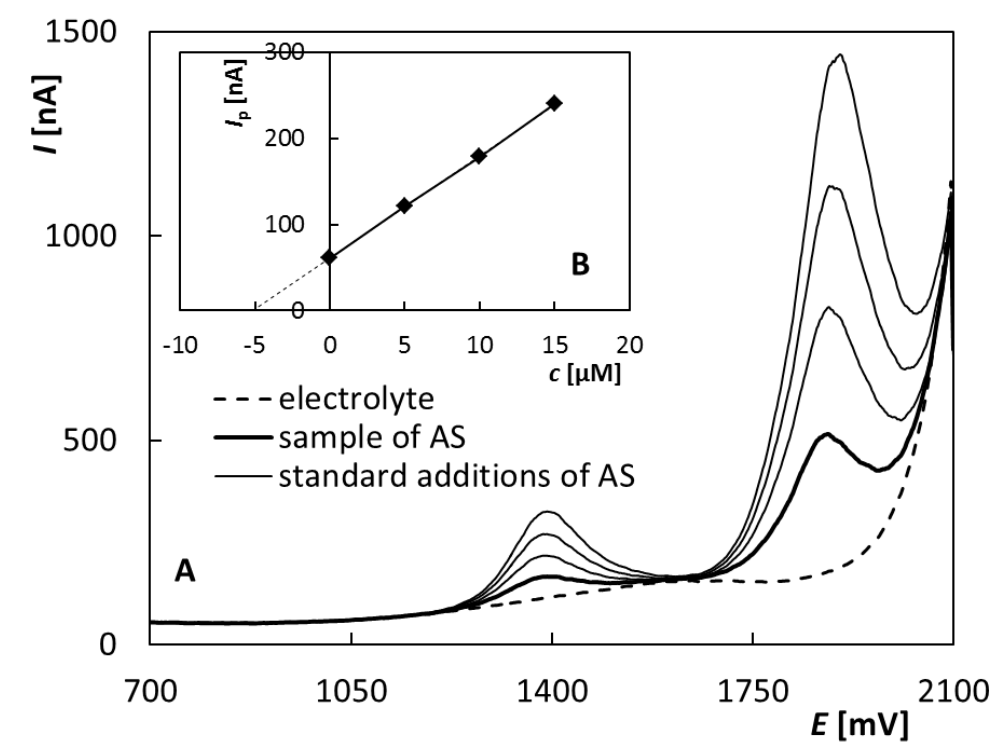

Fig. $6 \mathrm{~A}$ - DP voltammograms of AS determination in model solution $\left(c_{\mathrm{AS}}=5 \times 10^{-6} \mathrm{M}\right)$ using BDDE and standard addition method, B - graphical evaluation of standard addition method; $E_{\text {in }}=0 \mathrm{mV}, E_{\mathrm{fin}}=+2500 \mathrm{mV}, v=20 \mathrm{mV} \mathrm{s}^{-1}$, pulse height $=+60 \mathrm{mV}$, pulse width $=30 \mathrm{~ms}$, standard additions: $V=75 \mu \mathrm{l}, c=1.0 \times 10^{-3} \mathrm{M}$. 
Table 1 Results of repeated determination of AS in model solution (DPV, $E_{\text {in }}=0 \mathrm{mV}, E_{\text {fin }}=$ $+2500 \mathrm{mV}, v=20 \mathrm{mV} \mathrm{s}^{-1}$, pulse height $=+60 \mathrm{mV}$, pulse width $=30 \mathrm{~ms}$ ).

\begin{tabular}{cccc}
\hline AS concentration $[\mathrm{M}]$ & Found [M] & Recovery [\%] & RSD $_{5}[\%]$ \\
\hline $5.0 \times 10^{-6}$ & $(5.000 \pm 0.052) \times 10^{-6}$ & $98.4-102.4$ & 1.57 \\
$1.0 \times 10^{-6}$ & $(0.990 \pm 0.024) \times 10^{-7}$ & $96.0-103.0$ & 3.67 \\
\hline
\end{tabular}

\subsubsection{Interference study}

The interference study should be an integral part of each development of analytical method due to its potential application in real samples analysis. In our case, we focused on other fungicides and, in general, pesticides that may be present in analyzed samples along with the AS. Measured AS concentration in polarographic cell was $5.0 \times 10^{-6} \mathrm{M}$ and the concentration of tested interferents varied in ratio of AS to interferent compound of 1:0.1, 1:1, and 1:10, respectively. This means that the concentration of pesticides was $5.0 \times 10^{-7}, 5.0 \times 10^{-6}$, and $5.0 \times 10^{-5} \mathrm{M}$. The substance was considered to be interfering if its addition affected the original AS peak height by more than $5 \%$. The obtained results are summarized in Table 2.

The first part of this study focused on azole fungicides (difenoconazole, cyproconazole, propiconazole, epoxiconazole, and tebuconazole) that can often occur with AS in mixture in commercially available pesticide preparations. Cyproconazole, propiconazole as well as epoxiconazole did not provide any oxidation signal on BDDE under the proposed conditions and their additions did not influence AS peak. A slight decrease $(<6.5 \%)$ of AS $I_{\mathrm{p}}$ in the case of a 10-fold excess of cyproconazole and epoxiconazole was caused by increasing of proportion of organic solvent in solution which led to the narrowing of potential window and to the deterioration of AS peak evaluability. Difenoconazole and tebuconazole affected $I_{\mathrm{p}}$ of AS already at a ratio 1:1 due to the own oxidation signals situated at about $200 \mathrm{mV}$ more positive potential values and at a ratio 1:10 the AS peak becomes very poorly evaluable. Interference of tebuconazol is illustrated in Fig. 7A and B. However, this fact does not mean that AS cannot be determined next to difenoconazole or tebuconazole in pesticide preparations because the content of both interfering fungicides is usually similar or slightly lower as compared to the content of AS. It can be seen from the Fig. 6B that in this case both peaks (AS as well as tebuconazole) are well evaluable.

The second tested interferent group represents pesticides that can be applied to prevent the same crops as AS, namely herbicides glyphosate, triasulfuron, triclopyr, and tribenuron as well as insecticides imidacloprid and chlorpyriphos. The results in Table 2 show that most of 
the tested substances do not affect AS determination. Triasulfuron may also be assigned to these substances, because its excess has caused only slight decrease in the analyte response. The interference between triasulfuron and AS current responses is illustrated in Fig. 7C and D. Sole chlorpyriphos influenced significantly AS determination but again only in excess. Therefore, it is possible to conclude that the proposed method of AS determination can be selective enough for application in analysis of natural samples and pesticide preparations.

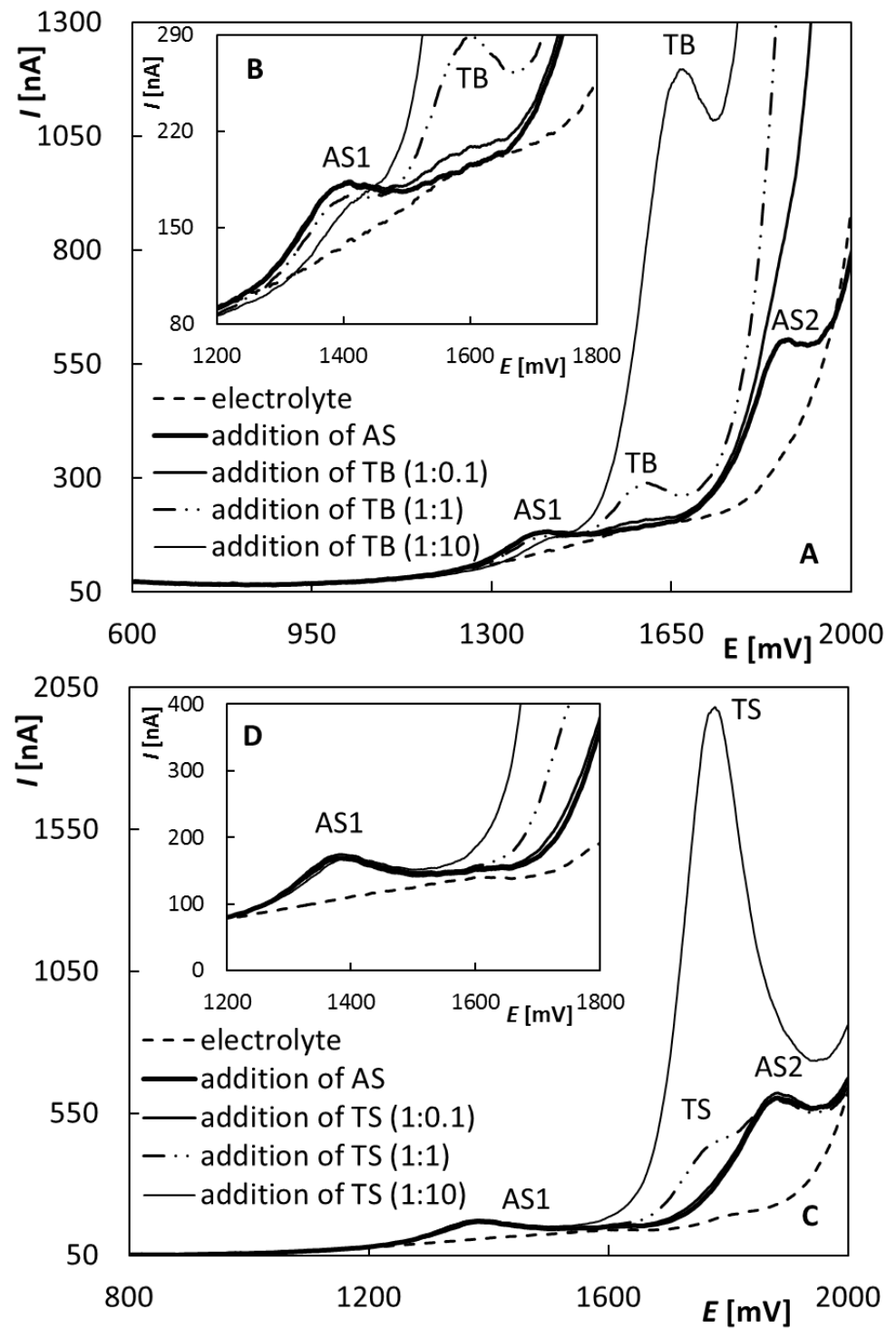

Fig. $7 \mathrm{~A}$ - DP voltammograms of $5 \times 10^{-6} \mathrm{M}$ AS in the presence of $5.0 \times 10^{-7}, 5.0 \times 10^{-6}$, and $5.0 \times 10^{-5} \mathrm{M}$ tebuconazole (TB) obtained on BDDE, B - detail of AS peak 1 (AS1) from Fig. A, C - DP voltammograms of $5 \times 10^{-6} \mathrm{M}$ AS in the presence of $5.0 \times 10^{-7}, 5.0 \times 10^{-6}$, and $5.0 \times 10^{-5} \mathrm{M}$ triasulfuron (TS) obtained on BDDE, D - detail of AS peak 1 from Fig. C; $E_{\text {in }}=$ $0 \mathrm{~V}, E_{\text {fin }}=+2.5 \mathrm{~V}, v=20 \mathrm{mV} \mathrm{s}^{-1}$, pulse height $=+60 \mathrm{mV}$, pulse width $=30 \mathrm{~ms}$. 
Table 2 Results of interference study for AS determination in presence of other pesticides $\left(\mathrm{DPV}, E_{\text {in }}=0 \mathrm{mV}, E_{\mathrm{fin}}=+2500 \mathrm{mV}, v=20 \mathrm{mV} \mathrm{s}^{-1}\right.$, pulse height $=+60 \mathrm{mV}$, pulse width $=$ $30 \mathrm{~ms}, c_{\mathrm{AS}}=5.0 \times 10^{-6} \mathrm{M}, c_{\text {interferent }}=5.0 \times 10^{-7}, 5.0 \times 10^{-6}$, and $\left.5.0 \times 10^{-5} \mathrm{M}\right)$.

\begin{tabular}{lccc}
\hline & Change of $I_{\mathrm{p}}$ in the presence of interferent [\%] \\
\hline Interferent & \multicolumn{3}{c}{$c_{\mathrm{AS}}: c_{\text {interferent }}$} \\
\hline difenoconazole & -1.6 & $1: 1$ & $1: 10$ \\
cyproconazole & +1.0 & -15.9 & -49.2 \\
propiconazole & +1.3 & +1.7 & -6.1 \\
epoxiconazole & +1.5 & +0.1 & -1.3 \\
tebuconazole & -1.6 & +1.0 & -5.9 \\
\hline triclopyr & +1.5 & -31.0 & -74.8 \\
imidacloprid & +1.6 & -0.9 & -7.4 \\
chlorpyriphos & -1.9 & +0.4 & -0.3 \\
triasulfuron & +2.9 & -3.6 & -57.7 \\
glyphosate & -0.4 & -0.9 & -13.3 \\
tribenuron & -0.7 & -1.3 & -0.7 \\
\hline
\end{tabular}

\subsubsection{Analysis of real samples}

Drinking and river water was analyzed as it is described in "Experimental". At the beginning, the concentration dependences of AS in range from $5.0 \times 10^{-7}$ to $5.0 \times 10^{-6} \mathrm{M}$ were measured in both water samples which can be described by equations (7) for drinking and (8) for river water. Calculated statistical parameters for AS determination are summarized in Table 3 together with those previously obtained for model solution. The values of $L O D$ and $L O Q$, respectively, are similar for all three types of matrices. Only the value of $R S D$ of 11 repeated measurement of $5.0 \times 10^{-6} \mathrm{M}$ AS slightly increased from model solution prepared in distilled water over the spiked drinking water to the natural river water, specifically from 0.47 to $3.62 \%$. However, all obtained values are below $5 \%$ which corresponds with very good repeatability sufficient for analytical purposes. Proposed method was also verified by repeated determination of AS in spiked drinking and river water using standard addition method and the results are shown in Table 4.

$I_{\mathrm{p}}[\mathrm{nA}]=(11.41 \pm 0.19) c[\mu \mathrm{M}], r=0.9992$

$I_{\mathrm{p}}[\mathrm{nA}]=(10.12 \pm 0.12) c[\mu \mathrm{M}]+(-0.39 \pm 0.27), r=0.9996$ 
Table 3 Statistical parameters of voltammetric determination of AS in model solutions, drinking and river water using BDDE (DPV, $E_{\text {in }}=0 \mathrm{mV}, E_{\text {fin }}=+2500 \mathrm{mV}, v=20 \mathrm{mV} \mathrm{s}^{-1}$, pulse height $=+60 \mathrm{mV}$, pulse width $=30 \mathrm{~ms}$ ).

\begin{tabular}{lccc}
\hline Sample & $\begin{array}{c}L O D \\
{[\mathrm{M}]}\end{array}$ & $\begin{array}{c}L O Q \\
{[\mathrm{M}]}\end{array}$ & $\begin{array}{c}R S D_{11} \\
{[\%]}\end{array}$ \\
\hline model solution & $8.4 \times 10^{-8}$ & $2.8 \times 10^{-7}$ & 0.47 \\
drinking water & $1.2 \times 10^{-7}$ & $4.1 \times 10^{-7}$ & 2.91 \\
river water & $8.0 \times 10^{-8}$ & $2.7 \times 10^{-7}$ & 3.62 \\
\hline
\end{tabular}

The last experiments were focused on voltammetric determination of AS in pesticide preparation "Ortiva". The procedure of sample pretreatment is described in "Experimental", standard addition method was applied for analysis evaluation. The found amount of AS corresponded with the content declared by producer as can be seen from Table 4. Also the repeatability of determination was sufficient $\left(R S D_{5}=2.38 \%\right)$.

Table 4 Results of repeated determination of AS in spiked water samples and pesticide preparation containing AS employing BDDE (DPV, $E_{\text {in }}=0 \mathrm{mV}, E_{\text {fin }}=+2500 \mathrm{mV}, v=$ $20 \mathrm{mV} \mathrm{s}^{-1}$, pulse height $=+60 \mathrm{mV}$, pulse width $=30 \mathrm{~ms}$ ).

\begin{tabular}{lcccc}
\hline Sample & Spiked $[\mathrm{M}]$ & Found $[\mathrm{M}]$ & Recovery [\%] & $R S D_{5}[\%]$ \\
\hline drinking water & $5.0 \times 10^{-6}$ & $(4.990 \pm 0.046) \times 10^{-6}$ & $98.4-101.8$ & 1.40 \\
river water & $5.0 \times 10^{-6}$ & $(5.0701 \pm 0.0083) \times 10^{-6}$ & $99.4-105.8$ & 2.47 \\
\hline-0 & Declared $\left[\mathrm{g} \mathrm{l}^{-1}\right]$ & Found $\left[\mathrm{g} \mathrm{l}^{-1}\right]$ & Recovery [\%] & $R S D_{5}[\%]$ \\
\hline Ortiva & 250 & $(251.1 \pm 3.9)$ & $97.4-102.7$ & 2.38 \\
\hline
\end{tabular}

\section{Conclusion}

The electrochemical oxidation of azoxystrobin, the world's largest-selling broad spectrum fungicide [46], on BDDE proceeds in two irreversible $\mathrm{pH}$-independent voltammetric waves. The first two-electron wave corresponds to oxidation of vinyl methyl ether portion of the $\beta$ methoxyacrylate moiety of the AS molecule yielding to a hydroxyl aldehyde functionality of the oxidation product. It is worth mentioning that the $\beta$-methoxyacrylate moiety is the toxophore of the azoxystrobin molecule and, at the same time, a reactive centre prone to oxidative metabolism catalysed by cytochrome P450 enzymes [47]. 
Voltammetric method for AS determination utilizing BDDE in connection with DPV was developed. First anodic signal in BRB of $\mathrm{pH} 2$ proved to be suitable for analytical purposes. The method provides a wide linear dynamic range $\left(3.0 \times 10^{-7}\right.$ to $\left.2.0 \times 10^{-4} \mathrm{~mol} \mathrm{~L}^{-1}\right)$ with limit of detection $8 \times 10^{-8} \mathrm{~mol} \mathrm{~L}^{-1}$. Interference study confirmed sufficient selectivity of the developed voltammetric method for the azoxystrobin determination in reals samples. It was verified by successful analysis of spiked river water samples as well as of pesticide preparations.

\section{Acknowledgements}

This work was supported by the grant project of The Czech Science Foundation (project No. 17-03868S) and by The University of Pardubice (projects No. SGSFChT_2018_003 and SD373001/82/30350(2016)).

\section{References}

[1] S. C. Knight, V. M. Anthony, A. M. Brady, A. J. Greenland, S. P. Heaney, D. C. Murray, K. A. Powell, M. A. Schulz, C. A. Spinks, P. A. Worthington, D. Youle, Annu. Rev. Phytopathol. 1997, 35, 349-372.

[2] E. T. Rodrigues, A. Moreno, T. Mendes, C. Palmeira, M. A. Pardal, Chemosphere 2015, 132, 127-134.

[3] U. Gisi, H. Sierotzki, A. Cook, A. McCaffery, Pest. Manag. Sci. 2002, 5, 859-867.

[4] H. Wanga, J. Wang, Q. Chena, M. Wang, T. Hsiang, S. Shanga, Z. Yu, Pestic. Biochem. Phys. 2016, 130, 52-58.

[5] Y. Han, T. Liu, J. Wang, J. Wang, Ch. Zhang, L. Zhu, Pestic. Biochem. Phys. 2016, $133,13-19$.

[6] E. T. Rodrigues, I. Lopes, M. A. Pardal, Environ. Int. 2013, 53, 18-28.

[7] S. K. Cho, A. M. A. El-Aty, J. H. Choi, Y. M. Jeong, H. Ch. Shin, B. J. Chang, Ch. Lee, J. H. Shim, J. Sep. Sci. 2008, 31, 1750-1760.

[8] W. Li, Y. J. Wu, D. M. Qin, Y. Ma, Y. J. Sun, S. P. Qiu, Chromatographia 2008, 67, 761-766.

[9] G. Di Bella, M. Saitta, F. Salvo, M. Nicotina, G. Dugo, Ital. J. Food Sci. 2003, 15, 427 432.

[10] I. Giza, U. Sztwiertnia, Acta Chromatogr. 2003, 13, 226-229.

[11] H. B. Bo, Y. Bi, L. R. Chen, Chinese J. Anal. Chem. 2005, 33, 695-698.

[12] S. Sundravadana, D. Alice, R. Samiyappan, S. Kuttalam, J. Braz. Chem. Soc. 2008, 19, 60-63. 
[13] T. Chonan, J. Food Hyg. Soc. Jpn. 2001, 42, 249-251.

[14] S. Polati, M. Bottaro, P. Frascarolo, F. Gosetti, V. Gianotti, M. C. Gennaro, Anal. Chim. Acta 2006, 579, 146-151.

[15] M. Catala-Icardo, C. Gomez-Benito, E. F. Simo-Alfonso, J. M. Herrero-Martinez, Anal. Bioanal. Chem. 2017, 409, 243-250.

[16] L. M. Ravelo-Pérez, Food Chem. 2008, 111, 764-770.

[17] P. Cabras, A. Angioni, V. L. Garau, F. M. Pirisi, V. Brandolini, J. AOAC Int 1998, 81, 1185-1189.

[18] D. Hu, X. Xu, T. Cai, W. Y. Wang, C. J. Wu, L. M. Ye, J. Food Protect. 2017, 80, 2112-2118.

[19] S. Noegrohati, E. Hernadi, S. Asviastuti, B. Environ. Contam. Tox. 2018, 100, 821-826.

[20] J. Lopez Flores, A. Molina Diaz, M. L. F. de Cordova, Anal. Chim. Acta 2007, 585, 185-191.

[21] W. F. Pacheco, A. Doyle, D. R. A. Duarte, C. S. Ferraz, P. A. M. Farias, R. Q. Aucelio, Food Anal. Meth. 2010, 3, 205-210.

[22] R. M. Dornellas, R. A. A. Munoz, R. Q. Aucelio, Microchem. J. 2015, 123, 1-8.

[23] R. M. Dornellas, D. B. Nogueira, R. Q. Aucélio, Anal. Meth. 2014, 6, 944-950.

[24] R. M. Dornellas, R. A. A. Franchini, A. R. da Silva, R. C. Matos, R. Q. Aucelio, J. Electrocanal. Chem. 2013, 708, 46-53.

[25] J. M. S. Almeida, C. A. T. Toloza, R. M. Dornellas, A. R. da Silva, R. Q. Aucélio, Int. J. Environ. Anal. Chem. 2016, 96, 959-977.

[26] R. M. Dornellas, T. F. Tormin, E. M. Richter, R. Q. Aucelio, R. A. A. Munoz, Anal. Lett. 2013, 47, 492-503.

[27] K. Patel, K. Hashimoto, A. Fujishima, Denki Kagaku 1992, 60, 659.

[28] G. M. Swain, R. Ramesham, Anal. Chem. 1993, 65, 345-351.

[29] K. Pecková, J. Musilová, J. Barek, Crit. Rev. Anal. Chem. 2009, 39, 148-172.

[30] K. Schwarzová-Pecková, J. Vosahlova, J. Barek, I. Sloufova, E. Pavlova, V. Petrak, J. Zavazalova, Electrochim. Acta 2017, 243, 170-182.

[31] R. Selesovska, B. Krankova, M. Stepankova, P. Martinkova, L. Janikova, J. Chylkova, M. Vojs, J. Electroanal. Chem. 2018, 821, 2-9.

[32] L. Janikova-Bandzuchova, R. Selesovska, K. Schwarzova-Peckova, J. Chylkova, Electrochim. Acta 2015, 154, 421-429.

[33] R. Selesovska, L. Janikova-Bandzuchova, J. Chylkova, Electroanalysis 2015, 27, 42-51.

[34] R. Selesovska, L. Janikova, J. Chylkova, Monats. Chem. 2015, 146, 795-805. 
[35] M. Brycht, P. Lochynski, J. Barek, S. Skrzypek, K. Kuczewski, K. SchwarzovaPeckova, J. Electroanal. Chem. 2016, 771, 1-9.

[36] J. Zavazalova, K. Prochazkova, K. Schwarzova-Peckova, Anal. Lett. 2016, 49, 80-91.

[37] Y. R. Dai, D. A. Proshlyakov, G. M. Swain, Electrochim. Acta 2016, 197, 129-138.

[38] R. F. Brocenschi, R. C. Rocha, B. Duran, G. M. Swain, Talanta 2014, 126, 12-19.

[39] L. Novotný, Fresenius J. Anal. Chem. 1998 362, 184-188.

[40] J. Skopalova, P. Bartak, P. Bednar, H. Tomkova, T. Ingr, I. Lorencova, P. Kucerova, R. Papousek, L. Borovcova, K. Lemr, Anal. Chim. Acta 2018, 999, 60-68.

[41] P. Kučerová, J. Skopalová, L. Kučera, J. Hrbáč, K. Lemr, Electrochim. Acta 2015, 159, 131-139.

[42] C. R. Wilke, P. Chang, AIChE Journal 1955, 1, 264-270.

[43] J. W. Thompson, T. J. Kaiser, J. W. Jorgenson, J. Chromatogr. A 2006, 1134, 201-209.

[44] J. F. García-Reyes, A. U. Jackson, A. Molina-Díaz, R. G. Cooks, Anal. Chem. 2009, 81, 820-829.

[45] K. Prochazkova, S. Baluchova, J. Vosahlova, K. Schwarzova-Peckova, in XXXVI Moderni Elektrochemicke Metody (Eds: T. Navratil, M. Fojta, K. Schwarzova), Lenka Srsenova-BEST SERVIS, Usti nad Labem 2016, pp. 171-175.

[46] S. Armstrong, J. Clough, Education in Chemistry 2009 , 46, 53-56.

[47] A. Rösch, M. Gottardi, C. Vignet, N. Cedergreen, J. Hollender, Environ. Sci. Technol. 2017, 51, 12784-12795. 